\title{
A POESia inCógnita: ELEMENTOS PARA UM ESTUdo da POÉtica do SPleEN de Paris
}

\author{
Eduardo Horta Nassif Veras
}

\section{O POETA INCÓGNITO}

No famoso poema em prosa "Perte d'auréole", Baudelaire (I, p. 352, grifo do autor $)^{2}$ nos fala da perigosa travessia de um enlameado bulevar

\footnotetext{
1 "Et quoi! Vous ici, mon cher? vous, dans un mauvais lieu! vous, le buveur de quintessences! vous, le buveur d'ambroisie! en vérité, il y a là de quoi me surprendre. / - Mon cher, vous connaissez ma terreur des chevaux et des voitures. Tout à l'heure, comme je traverssais le boulevard, en grande hâte, et que je sautillais dans la boue, à travers ce chaos mouvant où la mort arrive au galop de tous les côtés à la fois, mon auréole, dans un mouvement brusque, a glissé de ma tête dans la fange du macadam. Je n’ai pas eu le courage de la ramasser. J'ai jugé moins désagréable de perdre mes insignes que de me faire rompre les os. Et puis, me suis-je dit, à quelque chose malheur est bon. Je puis maintenant me promener incógnito, faire des actions basses, et me livrer à crapule, comme les simples mortels. Et me voici, tout semblable à vous, comme vous voyez! / - Vous devriez au moins faire afficher cette auréole, ou la faire réclamer par le commissaire. / - Ma foi! Non. Je me trouve bien ici. Vous seul, vous m’avez reconnu. D’ailleurs la dignité m'ennuie. Ensuite je pense avec joie que quelque mauvais poète la ramassera et s'en coiffera impudemment. Faire un heureux, quelle jouissance! et surtout un heureux qui me fera rire! Pensez à X, ou à Z! Hein! comme ce sera drôle!" [Mas o quê? Você por aqui, meu caro? Você, em um lugar tão baixo! Você, o bebedor de quintessências! Você, o comedor de ambrosia! Na verdade, isso muito me surpreende. / - Meu caro, você sabe do meu pavor dos cavalos e dos carros. Há pouco, enquanto atravessava o bulevar, com muita pressa, e saltitava na lama, no meio desse caos movente onde a morte chega a galope de todos os lados ao mesmo tempo, minha auréola, num movimento brusco, escorregou da minha cabeça na sujeira do macadame. Não tive coragem de pegá-la. Achei menos desagradável perder minhas insígnias que arriscar quebrar os ossos. E, depois, disse a mim mesmo, a desgraça serve
} 
parisiense, descrito como um "caos movediço onde a morte chega a galope de todos os lados ao mesmo tempo". Nessa travessia, o poeta se vê diante de uma escolha imposta pela queda de sua auréola, após um movimento brusco: arriscar seus ossos para recuperá-la ao chão ou abrir mão definitivamente dela. Diante da ameaça de morte, o poeta não hesita muito em continuar seu caminho sem a auréola, gozando a partir de então da clandestinidade que lhe permitirá, entre outras coisas, "praticar ações baixas, e entregar[-se] à crápula, como os simples mortais”. O poema coloca em cena duas visões antagônicas a respeito da poesia e da figura do poeta: a romântica, representada pelo interlocutor, que, ao se mostrar surpreso com a presença do poeta no meio da multidão, se refere a ele como "o bebedor de quintessências", "o comedor de ambrosia”; e a moderna, representada pelo próprio poeta incógnito, que ironicamente prefere perder sua insígnia divina a arriscar sua pele entre cavalos e carroças que transitam em alta velocidade no bulevar. Toda a cena é marcada por um registro cômico, a começar pela própria imagem de um poeta aureolado que saltita sobre a lama na tentativa de atravessar uma rua. Baudelaire consegue extrair esse efeito cômico de uma narrativa que reúne algumas das figuras mais graves que compõem seu imaginário poético: a travessia do caos da cidade moderna, a queda do poeta e a perda de sua condição privilegiada, o que nos convida a pensar o poema à luz da autoderrisão irônica que sempre caracterizou sua prática poética. ${ }^{3}$

Diversos poemas de Baudelaire tematizam a descida do poeta ao mundo dos mortais. Em "Bénédiction" (I, p. 7), poema que inaugura a primeira seção de Les fleurs du mal, assistimos à "aparição" do Poeta

para alguma coisa. Agora posso caminhar incógnito, praticar ações baixas e me entregar à crápula, como os simples mortais. E eis-me aqui, igualzinho a você, como pode ver! / Você deveria ao menos pôr um anúncio da perda dessa auréola, ou fazer uma queixa às autoridades. / - Ah! não. Estou bem assim. Apenas você me reconheceu. Aliás, a dignidade me entedia. Além disso, imagino com alegria que algum mau poeta irá apanhá-la e colocála na cabeça sem nenhum pudor. Fazer alguém feliz, que prazer imenso! E sobretudo um felizardo que me fará rir! Pense em X, ou em Z, hein! Como isso será engraçado!] (I, p. 352). 2 Nas referências à obra de Baudelaire (1975-1976), o numeral romano indica o tomo. A edição citada é a de Claude Pichois, publicada em dois volumes, na coleção "Bibliothèque de la Pléiade" da Gallimard. As referências iniciadas com a letra " $C$ " remetem à Correspondance de Baudelaire (1973), edição de Claude Pichois e Jean Ziegler, em dois volumes, também publicada pela Gallimard na mesma coleção (Cf. Referências Bibliográficas).

Todas as traduções utilizadas neste artigo são nossas.

3 Sobre a ironia nos poemas em prosa de Baudelaire, remeto o leitor à introdução do excelente livro de Steve Murphy Logiques du dernier Baudelaire (2007). 
(com "P" maiúsculo) "neste mundo" como consequência de um "decreto de potências supremas". No mesmo poema, que pode ser lido como uma espécie de paródia do nascimento de Cristo, o poeta se apresenta como um ser rejeitado pela mãe e explorado pela esposa, personagens representados no texto de maneira bastante caricatural. Também no conhecido poema "L'albatros" (I, p. 9) encontramos a alegoria do poeta exilado e transformado em objeto de zombaria pelos homens desse mundo. Assim como no poema anterior, neste, o Poeta (novamente grafado com inicial maiúscula) também é apresentado como "cômico" e "feio".

O tema da descida do poeta ao mundo dos mortais ganha novos contornos à medida que avançamos em direção aos poemas dos Tableaux parisiens e do Spleen de Paris. Em "Le soleil" (I, p. 83), segundo poema da segunda seção de Les fleurs du mal, o poeta (dessa vez grafado com inicial minúscula) é comparado ao sol que "desce às cidades" e "enobrece as coisas mais vis", introduzindo-se igualmente nos "hospitais" e nos "palácios". No embate entre o Poeta-Albatroz e o "mundo entediado", que o acolhe com desprezo e violência, e o poeta-solar que desce em todos os cantos da cidade moderna, sem distinção moral, em busca da beleza, há menos uma relação de oposição que uma espécie de aprendizado poético. Dessa forma, a imagem do sol vale mais por sua imaterialidade, isto é, por seu caráter maleável, que por sua luminosidade. A partir dos poemas que tematizam a cidade moderna, é possível dizer que a experiência poética de Baudelaire se horizontaliza. Em outras palavras, o problema da "descida" ou da "queda" do poeta se metamorfoseia na imagem da "travessia" do caos urbano, do mundo dos mortais. O poeta passa a ser aquele que percorre "as dobras sinuosas de uma grande capital, onde tudo, mesmo o horror, se dá aos encantos", ${ }_{4}$ no poema "Les petites vielles" (I, p. 89). A "cidade formigante, cidade plena de sonhos", $\mathrm{em}$ "Les sept vieillards" (I, p. 87 ), mostra-se, assim, como o principal objeto de interesse do poeta após a "descida". Esta, por sua vez, incialmente vivenciada como uma espécie de queda, abre-se, aos poucos, para o desenvolvimento de uma nova estratégia de sobrevivência poética, baseada no disfarce, "incomparável privilégio" do poeta que "pode a seu bel prazer ser ele mesmo e outra pessoa", "Les foules" (I, p. 291), e principalmente no anonimato, que lhe

4 “[...] les plis sinueux des vielles capitales, / Où tout, même l'horreur, tourne aux enchantements".

5 “[...] fourmillante cité, cité pleine de rêves".

Remate de Males, Campinas-SP, v. 37, n. 1, pp. 93-116, jan./jun. 2017 
permite "andar incógnito [...] como os simples mortais", "Perte d'auréole" (I, p. 352, grifo nosso). ${ }^{6}$

A insígnia divina do poeta torna-se então obsoleta; mais do que isso, torna-se um objeto pesado, na medida que impõe a ele uma marca que desperta a rejeição e a violência dos homens, impedindo-o, inclusive, de seguir seu passeio criativo no meio da multidão urbana. $O$ percurso empreendido pelo poeta no caos da cidade - no qual sua auréola, tal qual as asas do albatroz, aparece mais como um fardo que como um distintivo (ou talvez se defina como um fardo justamente por ser um distintivo) - pode ser entendida como uma dramatização poética de renovação da poesia lírica, que ataca, principalmente, sua dimensão institucional, isto é, sua imagem ao mesmo tempo sacralizada e anacrônica na sociedade francesa do Segundo Império. Para Walter Benjamin (1989, p. 143), que considera Les fleurs du mal como "a última obra lírica a exercer influência no âmbito europeu”, alguns dos principais temas da obra de Baudelaire "colocam em questão a possibilidade mesma de uma poesia lírica" (p. 143). O poema "Perte d'auréole" representaria, assim, o destronamento definitivo do "poeta de auréola", que, nas palavras do crítico alemão, "tornou-se antiquado para Baudelaire" (p. 143). Já para o crítico inglês Steve Murphy (2000, p. 193), "a derrota da poesia lírica tradicional seria o preço a pagar pela invenção de uma poesia pós-romântica e talvez, em alguns aspectos, pós-lírica”, que teria nos poemas em prosa de Baudelaire um de seus pontos de origem.

O processo de horizontalização da experiência poética representa menosuma ruptura interna napoética de Baudelairequeodesenvolvimento de seu próprio tema central. A meu ver, "Perte d'auréole" não coloca em cena um poeta antagônico àquele que inicia sua viagem em "Bénédiction", mas representa, graças principalmente a seu caráter cômico, uma espécie de descoberta que permite ao poeta sobreviver em tempos de rejeição à poesia. ${ }^{7}$ Para compreendê-lo, basta observar que a perda da auréola não promove a igualdade entre o poeta e seus concidadãos, mas

6 “[...] incomparable privilège, qu'il peut à sa guise être lui-même et autrui” e “[...] [me] promener incógnito [...] comme les simples mortels", respectivamente.

7 Walter Benjamin (1989, p. 103) observa que Baudelaire "teve em mira leitores que se veem em dificuldades ante a leitura da poesia lírica”, numa época em que "as condições de receptividade da poesia lírica se [tornaram] mais desfavoráveis” (p. 104). Possivelmente, essa transformação se explique pelo envelhecimento do modelo romântico baseado em uma visão profética do poeta e do discurso poético, ao qual a recepção ainda estava hipocritamente presa - enquanto lugar-comum. 
permite-lhe caminhar incógnito como se fosse um deles. Todo o diálogo encenado no poema aponta para a crítica das aparências, isto é, para o desvelamento crítico do fetiche poético simbolizado pela auréola, tratada pelo interlocutor como uma espécie de mercadoria cuja perda deveria ser relatada às autoridades, e para construção de uma nova trajetória poética indissociável da nova condição incógnita do poeta. Recusando, em última instância, o valor do objeto perdido, o poeta se diverte ao imaginar que algum mal poeta o encontrará e fará uso dele sem nenhum pudor. Baudelaire parece rejeitar o cliché do poeta-profeta enquanto distinção social, mas não me parece que recuse, com isso, a sua própria superioridade em relação à crápula, à qual, não obstante, ele diz querer se juntar. Essa superioridade não está mais ligada a um prestígio social, definitivamente perdido, mas à capacidade de rir de sua própria queda, de se "duplicar rapidamente e assistir como espectador desinteressado aos fenômenos de seu eu", ${ }^{8}$ conforme escreve Baudelaire (II, p. 532, grifo do autor) no ensaio "De l'essence du rire". Ela está intimamente ligada à capacidade de reconhecimento da humanidade do poeta em franca oposição à hipocrisia moral e religiosa da burguesia. Em outras palavras, a singularidadedo poeta não se encontra mais em um distintivo socialmente visível, aureolada por noções como dignidade e nobreza, mas no próprio arsenal crítico da poesia moderna, na capacidade de autoquestionamento do poeta que se humaniza e se aproxima ironicamente dos outros mortais.

A descida do poeta à cidade pressupõe o reconhecimento do caráter caótico da realidade urbana. Mais uma vez, o poeta se destacará como alguém que prefere dar conta criticamente da realidade a optar pela evasão - não raro hipócrita - de uma visão idealizada da modernidade ou de uma rejeição radical do presente histórico. ${ }^{9}$ A horizontalização da experiência poética em Baudelaire se realiza num contato de corpo a corpo com a cidade moderna e seus personagens. Incógnito, livre do peso de toda dignidade poética e encurtada a distância que sua insígnia divina lhe impunha em relação aos homens, o poeta percorre livremente as ruas de Paris, cujos personagens e anedotas aparecem, ao longo dos poemas, como um verdadeiro desafio à inteligência poética. Tentarei mostrar,

8"[...] se dédoubler rapidement et d'assiter comme spectateur désintéreséaux phénomènes de son moi."

9 No primeiro caso, poderíamos citar o exemplo de Maxime du Camp, que, em seus Chants modernes (1855), exalta o progresso técnico como uma marca da grandeza do homem moderno. No segundo caso, destaca-se o exemplo de Leconte de Lisle e sua poética voltada para o cultivo de temas e formas da Antiguidade.

Remate de Males, Campinas-SP, v. 37, n. 1, pp. 93-116, jan./jun. 2017 
neste artigo, que a condição do poeta “incógnito", disfarçado de pessoa comum, é um elemento central da poética da prosa baudelairiana, gênero que, em diversos aspectos, também parece recusar as aparências poéticas para se apresentar, sobretudo se consideramos sua relação com o suporte dos jornais, como um gênero perecível e despretensioso. Por trás desse disfarce, veremos que a poesia, ao se apresentar como encenação irônica da fraternidade e da banalidade, termina por se afirmar, paradoxalmente, em sua singularidade em face de seu próprio público e dos outros tipos de discurso dos quais simula uma aproximação.

A cena do poeta "incógnito"10 que caminha nas ruas de Paris deve ser tomada, portanto, como uma espécie de alegoria para a compreensão do projeto baudelairiano do livro de poemas em prosa, que o poeta não teve tempo de realizar plenamente antes de seu falecimento, em 1867. É preciso lembrar que as diversas edições dos poemas em prosa de Baudelaire que conhecemos, publicadas sob os títulos Le spleen de Paris e/ ou Petits poèmes en prose, tomam como referência a edição póstuma que aparece no quarto volume das Euvres complètes do poeta, organizadas por Charles Asselineau e Théodore de Banville e publicadas em 1869. A rigor, Le spleen de Paris é uma construção editorial realizada por "mãos alheias" (DUPONT, 2013, p. 41) a partir da reunião de poemas dispersos em jornais e revistas da época, aos quais foram acrescidos poemas inéditos encontrados nos arquivos do poeta. ${ }^{11}$ Quer consideremos o livro como uma composição legitimamente autoral ou como uma "ficção crítica", como afirmou recentemente Jacques Dupont, penso que é possível identificar

10 Em artigo recente, publicado nos números 13 e 14 da revista L'année Baudelaire, o crítico japonês Makoto Yokohari (2011) sugere que a figura do poeta incógnito na multidão parisiense é condição fundamental para a modernidade de Baudelaire e de seus poemas em prosa. Sua análise, que focaliza em especial a dicotomia baudelairiana do uno e do múltiplo, da solidão e da multidão, propõe um diálogo entre a obra de Baudelaire e o pensamento do filósofo neoplatônico Plotino, o que infelizmente acaba distanciando sua argumentação do contexto da modernidade.

11 Dos cinquenta poemas em prosa que compõem a edição póstuma de Le spleen de Paris publicada em 1869, cinco eram inéditos, não tendo sido publicados anteriormente em jornais e revistas; são eles: "Le galant tireur", "La soupe et les nuages", "Mademoiselle Bistouri”, “Assommons les pauvres!" e "Perte d'auréole”. Além desses textos, a edição contava ainda com um "Épilogue" em versos, que, entretanto, não constava do sumário preparado por Baudelaire em 1865. Para uma visão geral da história editorial do livro, cf. o apêndice esquemático do livro de Edward Kaplan (2015, pp. 227-233), Baudelaire et Le spleen de Paris: L'esthétique, l'éthique et le religieux, e o "Avant-propos" de André Guyaux (2014, pp. 7-10) ao livro Lire Le spleen de Paris de Baudelaire, organizado por ele em parceria com Henri Scepi.

Remate de Males, Campinas-SP, v. 37, n. 1, pp. 93-116, jan./jun. 2017 
no projeto poético de Le spleen de Paris um esforço intenso de organização poiética, cujas marcas se deixam perceber na edição póstuma, a despeito da inevitável manipulação editorial à qual ela foi submetida. Tentaremos recompor os principais traços dessa poética, que se constitui efetivamente na passagem do verso para a prosa, empreendida por Baudelaire, a partir da análise cotejada do contexto de publicação dos poemas, das referências ao projeto do livro nas correspondências do poeta e da própria estrutura do livro póstumo.

\section{UM LIVRO PÓSTUMO}

Para uma boa análise dos elementos que compõem a poética do Spleen de Paris é imprescindível considerar a relatividade de certas escolhas que orientaram a organização póstuma dos poemas em prosa de Baudelaire. Com essa proposta de desconstrução do livro de 1869 , procurarei não tanto evidenciar o caráter "ficcional" da obra enquanto livro, conforme a leitura provocadora de Jacques Dupont, mas abrir espaço para uma leitura mais global de um projeto literário que, a meu ver, deve ser compreendido em seu próprio inacabamento, como percurso parcialmente percorrido entre a publicação em jornais e a organização final de um livro de poemas. Desse projeto, tentarei analisar os principais resquícios teóricos e poéticos, começando por fazer o caminho de volta da edição póstuma do livro ao contexto de publicação dos poemas avulsos ou em pequenos grupos em jornais e revistas entre os anos de 1855 e 1867.

A primeira edição em livro dos poemas em prosa de Baudelaire foi editada e publicada postumamente sob os cuidados de Théodore de Banville e Charles Asselineau com o título Petits poèmes en prose. $\mathrm{O}$ livro constava do quarto volume das Euvres complètes (Paris, Michel Lévy Frères) do poeta, também composta por Les paradis artificiels. Sua estrutura, que é modelo para a imensa maioria das edições posteriores, é composta por cinquenta poemas em prosa, numerados de acordo com as indicações deixadas por Baudelaire (I, pp. 1.305-1.307) em nota de 1865, que preservam em geral a ordem cronológica da publicação em jornais e revistas, antecedidos pela carta-dedicatória endereçada ao editor da revista La Presse, Arsène Houssaye, em 1862, e sucedidos do "Épilogue" (I, 191), escrito em versos.

Qualquer estudo aprofundado e sério dos poemas em prosa de Baudelaire não pode deixar de levar em conta que praticamente todos os 
elementos que compõem a edição póstuma do livro resultam de escolhas editoriais alheias ao poeta. Do título ao epílogo em versos acrescentado equivocadamente por Banville e Asselineau, passando pelo número de poemas e pela escolha do prefácio, praticamente toda a estrutura dos Petits poèmes en prose é fruto de uma composição a posteriori. ${ }^{12} \mathrm{~A}$ análise de sua Correspondência nos mostra que Baudelaire (C, II, p. 583) se debateu, ao longo de quase uma década, com a difícil tarefa de conceber um livro que reunisse poemas ao mesmo tempo "penetrantes e leves" [pénétrante et légère]. A exasperação diante da dificuldade de realização do projeto, que dividia a atenção do poeta com outras tantas tarefas e projetos não concluídos, é um tópico recorrente em algumas cartas da década de 1860:

No Spleen de Paris haverá cem peças - ainda faltam trinta. Eu me impus distraidamente tantas tarefas variadas sobre os braços e tenho tido tantos contratempos em Paris que tomei a decisão de ir fazer as trinta peças em Honfleur (C, II, p. 324). ${ }^{13}$ [Carta ao editor Pierre-Jules Hetzel, de 8 de outubro de 1863]

O Spleen de Paris, esse livro maldito com o qual eu contava tanto, está parado na metade. Ah! como eu demoro para estar em casa! Decididamente há um grande perigo em deixar um trabalho por muito tempo interrompido, e em fazer muitas coisas ao mesmo tempo (C, II, p. 417). ${ }^{14}$ [Carta a Madame Aupick, de 3 de novembro de 1864]

Ai de mim! os Poemas em prosa aos quais você ainda havia lançado um encorajamento recente estão muito atrasados. Eu me imponho sempre sobre os braços tarefas muito difíceis. Fazer cem bagatelas laboriosas que exigem um bom humor constante (bom humor necessário até para tratar de temas tristes), uma excitação bizarra que precisa de espetáculos, multidões, música, iluminação pública, eis o que eu quis fazer! Eu tenho apenas sessenta, e não consigo mais avançar. Preciso daquele famoso banho de multidão cuja

$12 \mathrm{O}$ poema em terza rima que faz uma homenagem à cidade de Paris, contemplada pelo poeta do alto da colina de Montmartre, foi descoberto por Banville e Asselineau e acrescentado à edição póstuma dos poemas em prosa organizada por eles. Cem anos depois, coube a Robert Kopp (BEAUDELAIRE, 1968, pp. 369-375), em sua edição dos Petits poèmes en prose, demonstrar que o poema, na verdade, havia sido composto como epílogo de Les fleurs du mal. Cf. nota de Claude Pichois ao poema (I, p. 1.175).

13 "Dans Les spleen de Paris, il y aura cent morceaux - il en manque encore trente. Je me suis mis étourdiment tant de besognes variées sur les bras et j'ai tant d'ennuis à Paris que j'ai pris le parti d'aller faire vos trente morceaux à Honfleur."

14 "Le spleen de Paris, ce maudit livre sur lequel je comptais tant, est resté suspendu à la moitié. Ah! qu'il me tarde d'être chez moi! Il y a décidément un grand danger à laisser longtemps un travail interrompu, et à faire plusieurs choses à la fois.”

Remate de Males, Campinas-SP, v. 37, n. 1, pp. 93-116, jan./jun. 2017 
A poesia incógnita: elementos de um estudo da poética do Spleen de Paris - 101

incorreção lhe chocou com razão (C, II, p. 493, grifo do autor). ${ }^{15}$ [Carta a SainteBeuve, de 4 de maio de 1865 ]

Ah! esse Spleen, quanta cólera, e quanto labor ele me causou! E eu continuo descontente com certas partes (C, II, p. 627). ${ }^{16}$ [Carta a Jules Troubat, de 5 de março de 1866]

Baudelaire atribuía uma grande importância ao projeto de composição de um livro de poemas em prosa (C, II, p. 295) que não se confundissem com esboços de poemas em verso (C, II, p. 207). ${ }^{17}$ A complexidade da tarefa, que deveria aliar humor, profundidade, leveza, ironia, além de espelhar os múltiplos estímulos sensoriais da vida urbana, parece ter contribuído para os constantes atrasos na finalização do livro. Baudelaire buscava uma espécie de síntese entre a originalidade e a acessibilidade comercial, entre o humor e a filosofia, entre a anedota e a reflexão moral. O livro prometido por ele ao editor Pierre-Jules Hetzel seria ao mesmo tempo "singular e fácil de vender" [Singulier et facile à vendre] (C, II, p. 295). Não por acaso, o poema em prosa é definido frequentemente como "uma aliança de contrários" [une alliance des contraires] (COMPAGNON, 2014, p. 54) que não deixa de guardar relações com a "tática particular aos jornalistas, que consiste em comparar coisas distintas", conforme afirma Baudelaire (I, p. 571) em trecho da novela La Fanfarlo. ${ }^{18}$ Essa relação com os jornais, aos quais a maioria dos poemas em prosa foi destinada, é, a meu ver, a principal chave de compreensão da poética da prosa em Baudelaire, pois seus poemas em prosa devem ser entendidos não mais como poemas publicados na imprensa, mas como poemas em sua grande maioria concebidos para esse tipo de suporte e seu público.

15 "Hélas! les Poèmes en prose, auxquels vous avez encore décoché un encouragement récent, sont bien attardés. Je me mets toujours sur les bras des besognes difficiles. Faire cent bagatelles laborieuses qui exigent une bonne humeur constante (bonne humeur nécessaire même pour traiter des sujets tristes), une excitation bizarre qui a besoin de spectacles, de foules, de musique, de réverbères même, voilà ce que j’ai voulu faire! Je n'en suis qu'à soixante, et je ne peux plus aller. J'ai besoin de ce fameux bain de multitude dont l'incorrection vous avait justement choqué."

16 "Ah! ce Spleen, quelles colères, et quel labeur il m’a causé! Et je reste mécontent de certaines parties."

17 Coma possível exceção de "Un hemisphère dans une chevelure”, composto provavelmente antes de "La chevelure", em todos os casos em que há correspondência direta entre poemas em verso e poemas em prosa, a versão em prosa é sempre posterior. Cf. notas de Claude Pichois a Le spleen de Paris (I, p. 1.301).

18 "[...] tactique particulière aux journalistes, qui consiste à comparer des choses dissemblables."

Remate de Males, Campinas-SP, v. 37, n. 1, pp. 93-116, jan./jun. 2017 
Quanto ao livro, Baudelaire o perseguiu ao longo de sua última década de vida, referindo-se constantemente a ele em conversações privadas e prometendo-o a editores interessados na publicação. Em carta a Arsène Houssaye, editor a quem dedicara uma série de poemas em prosa em 1862, Baudelaire se refereaodesejo de oferecer ao editor Hetzel o pequenovolume de poemas em prosa (C, II, p. 208); alguns meses depois, escrevendo para sua mãe, menciona outra vez o interesse de Hetzel em publicar os mesmos poemas em volume ${ }^{19}$ (C, II, p. 238); e, finalmente, no segundo semestre de 1862, inclui os Poèmes en prose em uma lista de "matéria vendável" [matière vendable], ao lado de outros quatro trabalhos (Réflexions sur mes contemporains, Fleurs du mal e Paradis artificiels), que constam de uma carta (C, II, p. 256) endereçada a Auguste Poulet-Malassis. Ao longo desse período marcado concomitantemente pela elaboração de uma nova poética e pelas constantes tentativas de inserir seus poemas em prosa nos jornais, pelo menos nove possíveis títulos foram cogitados pelo poeta e/ou utilizados pelos editores em publicações parciais: Poèmes nocturnes ( $\mathrm{C}, \mathrm{I}$, p. 395; C, I, p. 441; C, I, p. 418; C, I, p. 128; Le présent, 24 de agosto de 1857), ${ }^{20}$ Poèmes en prose (Revue Fantaisiste, edição de 1 de novembro de 1861), Le promeneur solitaire (C, II, p. 208), Le rôdeur parisien (C, II, p. 208), La lueur et la fumée. Poème, en prose (C, II, p. 197), Petits poèmes en prose (La Presse, edições de 26 e 27 de agosto e 24 de setembro de 1862; Revue Nationale et Étrangère, edições de 10 e 15 de junho e de 10 de dezembro de 1863; L'artiste, 1 de novembro de 1864), Le spleen de Paris. Poèmes en prose (Le Figaro, edição de 7 de fevereiro de 1864; Revue de Paris, edição de 25 de dezembro de 1864), Petits poèmes lycanthropes (Revue du XIXe Siècle, edição de 1 de junho de 1866) e, finalmente, Le spleen de Paris (C, II, p. 295; L'Événement, edição de 12 de junho de 1866, na qual foi publicado apenas o poema "La corde"). De Poèmes nocturnes a Le spleen de Paris, a lista de títulos reflete as "incertezas fecundas" (I, p. 1.298) do poeta e aponta para uma aproximação progressiva entre o projeto dos poemas em prosa e Les fleurs du mal. Conforme observa Claude Pichois, "Le spleen de

\footnotetext{
19 Baudelaire (C, II, p. 354) atribuiu também ao editor Albert Collignon o interesse de publicar em volume os poemas em prosa, o que, todavia, a exemplo do caso de Hetzel, jamais aconteceu.

20 Na carta de 9 de fevereiro de 1861, endereçada a Armand du Mesnil, Baudelaire (C, II, p. 128) acrescenta ao título Poèmes nocturnes o seguinte subtítulo: "essais de poésie lyrique en prose, dans le genre de Gaspard de la nuit" [ensaios de poesia lírica em prosa, no gênero de Gaspar de La nuit], referindo-se ao livro de poemas em prosa de Aloysius Bertrand, considerado por parte da Crítica como o precursor do gênero poema em prosa.
}

Remate de Males, Campinas-SP, v. 37, n. 1, pp. 93-116, jan./jun. 2017 
Paris é o único título atestado com certeza nos últimos anos da vida de Baudelaire" (I, p. 1.299), ${ }^{21}$ o que justifica sua adoção pela grande maioria dos editores. Ao diálogo temático com o livro de poemas em verso deve-se acrescentar ainda a intenção do poeta de instituir também uma espécie de paralelismo estrutural entre as duas obras. Baudelaire (C, II, p. 324) previa um livro com cem poemas em prosa, exatamente o mesmo número de peças em verso que compunham a primeira edição das Flores, publicada em 1857. Com efeito, conforme nos mostra a Correspondência do poeta, Le spleen de Paris foi concebido para funcionar como livro simétrico a Les fleurs du mal (C, II, p. 512), porém com "mais liberdade, detalhe e zombaria" (C, II, p. 615). ${ }^{22}$

Antes de explorar mais atentamente a relação entre os dois livros de Baudelaire e demonstrar como ambos foram planejados pelo poeta como organismos poéticos, é preciso avançar um pouco mais na relativização estrutural da versão póstuma de Le spleen de Paris organizada por Banville e Asselineau. Além das incertezas sobre o título do livro, a quantidade, a ordem e a versão definitiva dos poemas, também é possível questionar a escolha da carta-dedicatória a Arsène Houssaye como prefácio da edição póstuma. ${ }^{23}$ Esse texto, considerado por muitos como uma espécie de arte poética de Le spleen de Paris, concerne em especial às quatro séries de poemas em prosa destinadas ao jornal La Presse entre agosto e setembro de 1862. Arsène Houssaye, diretor literário do periódico, acolhe as três primeiras séries em 26 e 27 de agosto e 24 de setembro daquele ano, mas recusa o quarto folhetim, previsto para o dia 27 de setembro, do qual nos resta uma prova corrigida por Baudelaire. O projeto de publicação dos poemas em prosa em La Presse é um documento precioso para a compreensão da poética de Le spleen de Paris; as quatros séries são compostas pelos primeiros vinte e seis poemas da edição póstuma (mais da metade do livro), dispostos numa ordem que deixa transparecer uma intenção organizadora que não pode ser negligenciada pelo intérprete da obra. As séries se organizaram da seguinte forma:

21 "Le spleen de Paris est le seul titre attesté avec certitude durant les dernières années de la vie de Baudelaire."

22 "[...] beaucoup plus de liberté, et de détail, et de raillerie."

23 Jacques Dupont (2013, p. 46) argumenta que a carta-dedicatória endereçada a Arsène Houssaye só é válida para a série de poemas publicados sob os cuidados do editor no jornal La Presse em 1862. Dupont apresenta, como outra possibilidade de prefácio, o texto de apresentação (I, p. 1.297) dos poemas publicados no jornal Figaro nos dias 7 e 14 de fevereiro de 1864, escrito pelo jornalista Gustave Bourdin.

Remate de Males, Campinas-SP, v. 37, n. 1, pp. 93-116, jan./jun. 2017 
$1^{\text {a }}$ série: 26 de agosto de 1862

À Arsène Houssaye (carta-dedicatória)

I. L'étranger

II. Le désespoir de la vielle

III. Le "confiteor" de l'artiste

IV. Un plaisant

V. La chambre double

VI. Chacun la sienne (Chacun sa chimère)

VII. Le fou et la Vénus

VIII. Le chien et le flacon

XI. Le mauvais vitrier

$2^{\mathrm{a}}$ série: 27 de agosto de 1862

$X$. À une heure du matin

XI. La femme sauvage et la petite-maîtresse

XII. Les foules

XIII. Les veuves

$\mathrm{XIV}$. Le vieux saltimbanque

$3^{\mathrm{a}}$ série: 24 de setembro de 1862

XV. Le gâteau

XVI. L'horloge

XVII. Un hémisphère dans une chevelure

XVIII. L'invitation au voyage

XIX. Le joujou du pauvre

$\mathrm{XX}$. Les dons des fées

$4^{\mathrm{a}}$ série (recusada pelo editor)

XXI. Les tentations, ou Éros, Plutus et la gloire

XXII. Le crépuscule du soir

XXIII. Les projets

XXIV. La solitude

XXV. La belle Dorothée

XXVI. Les yeux des pauvres

Dos vintes e seis poemas selecionados por Baudelaire para as publicações no jornal La Presse em 1862, dezessete eram inéditos e nove já haviam aparecido anteriormente em outros periódicos, ${ }^{24}$ fato que teria motivado a recusa de Houssaye e a interrupção das publicações antes da aparição da quarta série. A republicação dos poemas parece ter indignado o editor do jornal, a julgar pela carta que Baudelaire (C, II, pp. 263-264)

24 "Les foules"; "Les veuves"; "Le vieux saltimbanque”; "L'horloge”; "Un hemisphere dans une chevelure”; "L'invitation au voyage”; "Le crépuscule du soir"; "Les projets e La solitude”. 
lhe endereça em 8 de outubro de 1862, logo após tomar conhecimento dos reproches de Houssaye e de sua decisão de suprimir os poemas em prosa do folhetim de La Presse. O poeta, que não via grandes problemas na retomada de poemas já publicados, apresenta três justificativas para o fato: 1) a insignificância dos periódicos anteriores, de "publicidade nula” (C, II, p. 263); 2) o remanejamento e a transformação de muitas das peças republicadas; e, finalmente, 3) sua intenção de apresentar ao leitor "uma ideia completa da obra em sua amplitude" (C, II, p. 264). ${ }^{25}$ O desejo de Baudelaire em apresentar aos leitores do jornal um todo orgânico não se contrapõe ao caráter fragmentado das publicações em folhetim. Ironicamente, a ideia do corte, da interrupção, da fragmentação já aparecia como elemento incorporado ao projeto dos poemas em prosa na carta-dedicatória a Arsène Houssaye, a qual encabeçava a primeira série de poemas publicada em La Presse:

Podemos cortar onde quisermos, eu, o meu devaneio, você, o manuscrito, o leitor, a sua leitura; pois não pretendo suspender a vontade teimosa desse último no fio interminável de uma intriga supérflua. Tire uma vértebra, e os dois pedaços dessa tortuosa fantasia irão se juntar novamente sem esforço. Corte-a em muitos fragmentos, e você verá que cada um pode existir à parte. $\mathrm{Na}$ esperança de que alguns desses pedaços estejam suficientemente vivos para lhe agradar e diverti-lo, ouso dedicar-lhe a serpente inteira (I, p. 275). ${ }^{26}$

O organismo poético concebido por Baudelaire se caracteriza pela independência do todo em relação às partes e das partes em relação ao todo. Recorrendo a metáforas orgânicas (vértebras, serpente, rabo, cabeça), o poeta procura conciliar os universos da literatura e do jornal, da publicação em livro e da publicação em folhetim. Esse esforço de conciliação aponta para a mesma ambivalência que Antoine Compagnon (2014) identificou na relação que o poeta estabeleceu com os jornais enquanto suporte e com os jornalistas e editores que acolheram seus textos. ${ }^{27}$ Em seu livro Baudelaire, l'irréductible, Compagnon (2014, p. 68) observa que o poeta

25 "Publiciténulle”; “[...] uneidéecomplètedel'ouvragedans sonampleur”, respectivamente. 26 "Nous pouvons couper où nous voulons, moi ma rêverie, vous le manuscrit, le lecteur da lecture; car je ne suspends pas la volonté rétive de celui-ci au fil interminable d'une intrigue superflue. Enlevez une vertebre, et les deux morceaux de cette tortueuse fantaisie se rejoindront sans peine. Hachez-la en nombreux fragments, et vous verrez que chacun peut exister à part. Dans l'espérance que quelques-uns de ces tronçons seront assez vivants pour vous plaire et vous amuser, j'ose vous dédier le serpente tout entier."

27 Compagnon (2014, p. 76) ressalta que Baudelaire estabeleceu uma relação essencialmente ambígua com os jornalistas e com os jornais. Dependia deles para publicar seus textos, mas se indispondo constantemente contra eles, inclusive fazendo uso das páginas dos próprios Remate de Males, Campinas-SP, v. 37, n. 1, pp. 93-116, jan./jun. 2017 
e o editor de La Presse concebiam a poesia e o folhetim de maneiras opostas. Enquanto Houssaye corrigia os originais de Baudelaire como fazia com qualquer outro texto do jornal, o poeta se mostrava atento à manutenção dos mínimos detalhes em suas peças, da seleção vocabular ao mais aparentemente insignificante sinal de pontuação. $\mathrm{O}$ desprestígio da literatura no espaço dos jornais não era, contudo, uma novidade para ele, que em 1846 já afirmava que "a literatura, que é a matéria mais inapreciável, - é antes de tudo um preenchimento de colunas" (II, pp. 1415). ${ }^{28}$ Acredito que esse rebaixamento da literatura - e mais especialmente da poesia - à função de preenchimento do vazio gráfico dos jornais também não é estranho ao projeto poético da prosa baudelairiana. Tal qual o poeta sem auréolas que se desloca incógnito no meio da multidão parisiense, a inserção da poesia de Baudelaire nos folhetins da época evidencia sua intenção de conquistar novos terrenos para a poesia - no caso, terrenos hostis ou indiferentes à própria existência dela.

\section{ORGANISMOS POÉTICOS}

O caráter orgânico do livro planejado por Baudelaire nos traz de volta ao problema da relação com o livro de versos. Em carta já citada a Julien Lemer, de 6 de julho de 1865, da qual consta uma lista de obras escritas e planejadas, o poeta acrescenta um parêntese explicativo quando se refere a Le spleen de Paris ("pour faire pendant aux Fleurs du mal" [para fazer simetria com as Flores do mal]), indicando que sua pretensão era conceber um livro de poemas em prosa que estabelecesse uma relação de simetria com o livro de poemas em verso (C, II, p. 512). Essa relação de simetria passava pelo número de poemas (Baudelaire planejava, como dito acima, um livro com cem poemas em prosa, o mesmo número de peças em verso da primeira edição de Les fleurs du mal (C, II, p. 324) e pelo contraste entre a gravidade do poema em verso e a "liberdade", o "detalhe" e a "zombaria" do poema em prosa, conforme sugere o poeta na carta a Jules Troubat de 19 de fevereiro de 1866 (C, II, p. 615), também já citada.

É preciso lembrar que Baudelaire insistiu diversas vezes no caráter orgânico do livro de poemas em verso. Para ele, "um livro de poesia deve

jornais para ironizar o jornalismo, como podemos ver em poemas como "À une heure du matin" e "Les tentations".

28 "[...] la littérature, qui est la matière plus inapréciable, - est avant tout un remplissage de colonnes [...]”.

Remate de Males, Campinas-SP, v. 37, n. 1, pp. 93-116, jan./jun. 2017 
ser apreciado em seu conjunto e por sua conclusão" (I, p. 193; grifo do autor). ${ }^{29}$ Nas notas que elaborou para seu advogado para a defesa de sua obra contra a acusação do Estado francês de "atentado à moral religiosa e atentado à moral pública" (I, p. 1.178), direcionada a treze poemas da primeira edição de Les fleurs du mal, Baudelaire afirma que "o livro deve ser julgado em seu conjunto, e então dele sairá uma terrível moralidade" (I, p. 193; grifo do autor)..$^{\circ}$

A despeito das inúmeras variações editorais, como a retirada dos seis poemas finalmente condenados pelos tribunais franceses e a inclusão da seção intitulada “Tableaux parisiens” (contendo trinta etrês novos poemas) na segunda edição de Les fleurs du mal (1861), muito se especulou sobre a "arquitetura" da obra. É o que observa Walter Benjamin (1989, p. 132) em sua proposta de leitura do livro a partir da divisão em ciclos. Também Hugo Friedrich (1991, p. 40) propôs uma leitura arquitetônica da obra, interpretando a sequência das seis seções que compõem a edição de 1861 como uma "parábola de cima para baixo", começando pelo contraste entre o "voo e a queda", que marca a seção inicial, até terminar com a descida ao abismo no poema final, "Le voyage”. O movimento dialético que coloca em tensão elementos opostos também orientou a leitura arquitetônica de James Lawler (1993, p. 9), para quem o mérito do poeta está justamente na criação de um eu-poético que se desloca de motivo em motivo para "qualificar e requalificar cada movimento do texto, e de quem o propósito definitivo não se encontraria nem em uma peça nem em outra, mas no conjunto acabado".

Quanto aos poemas em prosa, cuja fortuna crítica ainda é bem menos numerosa que aquela de Les fleurs du mal, a dispersão dos poemas em jornais e revistas e a intervenção de terceiros na edição póstuma do livro de 1869 dificultam ainda mais qualquer tentativa de leitura arquitetônica. A Crítica vem tentando, contudo, propor leituras orgânicas do conjunto em prosa. Destaco, entre as mais poderosas, a do crítico americano Edward Kaplan (2015), que, em Baudelaire et Le spleen de Paris: l'esthétique, l'éthique et le religieux, apresenta uma leitura dos poemas como fábulas modernas divididas entre o idealismo estético, a consciência ética e a aspiração religiosa pelo absoluto. Na visão do crítico,

29 “[...] un livre de poésie doit être apprécié dans son ensemble et pas sa conclusion". 30 "[...] atteinte à la morale religieuse et atteinte à la morale publique" e "Le livre doit être jugé dans son ensemble, et alors il en ressortira une terrible moralité", respectivamente. 
[...] essa tensão entre pathos ético e paixão imperiosa por um ideal de beleza sustenta todo o livro de maneira dinâmica e se declina em conflitos entre fantasma e realidade, entre espaço mental e espaço social, entre a inocência e o mal (KAPLAN, 2015, p. 40).31

A leitura dos poemas em prosa como fábulas que se opõem umas às outras a partir da dicotomia entre o ético e o estético, que, por sua vez, declinar-se-ia em oposições menores, independe da intencionalidade do autor por trás da organização dos livros. Embora a posição dos poemas no conjunto não seja um elemento insignificante, como sugere Jean-Marie Gleize (2007, p. 170), ao observar que o livro de Baudelaire inicia-se nas nuvens evocadas em L'étranger e termina com os vira-latas imundos e prosaicos de Les bons chiens, ela não me parece essencial para uma leitura arquitetônica da obra, que se sustenta também pelo viés da "fragmentação" e das múltiplas combinações, conforme a carta-dedicatória do poeta a Arsène Houssaye. Como a serpente convocada pelo poeta como metáfora para a estrutura de seu Spleen de Paris, o conjunto de poemas pode ser tomado em parte, pode ser "cortado em muitos fragmentos" [coup terrible, lourd [...] retenti à la porte] (I, p. 281) sem prejuízo para a sua significação. Ao contrário, parece-me que o seu sentido último reside justamente no conflito entre a fragmentação e a unidade, a multiplicidade e a ordem, o dinamismo e a estaticidade (ou a viagem e o domicílio, em termos mais baudelairianos), o jornal e o livro, em suma. Nesse movimento entre "o espaço mental e o espaço social" [l'espace mental et l'espace social] (I, p. 15), nos termos de Kaplan - que proponho traduzir nos termos de uma poesia que se abre, incógnita, para o universo prosaico sem, contudo, se perder completamente na multidão, isto é, mantendo sua identidade na solidão do poeta que afirma sua diferença -, se delineia o projeto poético da prosa baudelairiana, uma poesia que se afirma ao testar seus próprios limites, suas próprias fronteiras.

\section{A POESIA INCÓGNITA}

Retomemos, por um momento, a oposição entre idealismo estético e “pathos ético", proposta por Edward Kaplan, compreendendo o segundo termo da antítese de maneira mais alargada como manifestação da

31 “[...] cette tension entre pathos éthique et passion impérieuse pour un idéal de beauté sous-tend tout le recueil de façon dynamique et se décline en conflits entre fantasme et réalité, entre espace mental et espace social, entre l'innocence et le mal." 
consciência crítica da realidade. O conjunto de poemas em prosa pode ser dividido entre poemas que se apresentam como experiências oníricas, extáticas, fantasiosas, de um lado, e poemas que representam uma espécie de ruptura do ideal estético lírico, aproximando-se da realidade prosaica, tanto no plano do conteúdo quanto no do estilo, apresentando-se, dessa forma, como instrumentos de corte crítico no plano geral da obra; penso que essa dinâmica foi exemplarmente simbolizada no poema "La chambre double", que opõe, a partir da imagem do quarto, o espaço do sonho, da espiritualidade e do belo, ao espaço do horror, do tédio, do trivial, onde a temporalidade reina absoluta. A passagem de um quarto a outro se dá a partir da intervenção de um elemento crítico, metaforizado no poema pela "batida terrível, pesada [...] na porta" (I, p. 281), que faz o poeta despertar abruptamente do devaneio estético, desvelando a ilusão poética na qual estava imerso. Nesse sentido, é possível afirmar, com Barbara Johnson (1979, p. 50), que o "poema em prosa [baudelairiano] substitui as correspondências por diferenças [...], as fusões por separações”. ${ }^{2}$ Daí seu caráter revolucionário, conforme a análise de Johnson, sua capacidade de colocar em xeque a própria experiência poética conforme ela era concebida, por exemplo, em Les fleurs du mal.

A dinâmica de Le spleen de Paris se define, portanto, como um jogo de retomada e desconstrução do lirismo tradicional (constantemente associado à ilusão poética), de aproximação e distanciamento da realidade material, de enclausuramento e abertura do eu para o mundo social. Aqui, afasto-me da leitura de Barbara Johnson, para quem o processo de desfiguração levado a cabo pela reflexividade crítica dos poemas em prosa de Baudelaire promoveria uma espécie de suspensão do sentido. Prefiro pensar, novamente com Edward Kaplan (2015, p. 13, grifo do autor), que "esses textos podem ser interpretados sem que sua verdadeira complexidade, sua originalidade ou as tensões internas que os atravessam sejam ignoradas ou diminuídas". 33

A interpretação que arriscarei apresentar se baseia no movimento de abertura e fechamento do poeta em relação à vida social, e de aproximação e distanciamento da poesia em relação a si mesma, isto é, em relação à tradição da poesia lírica (ao verso, ao canto, ao tema nobre). Assim como

32 "[...] e poème en prose remplace les correspondances par des différences [...] les fusions par des séparations.”

33 "[...] ces textes peuvent être interprétés sans que leur véritable complexité, leur originalité ou les tensions internes qui les traversent s'en trouvent ignorés ou diminuées." 
o poeta de "Perte d'auréole", que se alegra por poder andar incógnito, como um simples mortal, no meio da multidão parisiense, acredito que sua poesia também almeja à mesma condição incógnita quando simula uma aproximação na direção do lugar-comum da vida urbana e dos jornais de grande circulação.

Muitos poemas do conjunto do Spleen de Paris, se interpretados metapoeticamente, oferecem ao leitor imagens que apontam para as oposições citadas acima. Comecemos pela oposição entre os espaços privado e social, entre a solidão do poeta e sua inserção na multidão urbana. Baudelaire (I, p. 313) faz o elogio da solidão no poema " $L a$ solitude" em resposta a um "jornalista filantropo que [lhe] diz que a solidão é ruim para o homem; e que, em apoio de sua tese, cita, como todos os incrédulos, palavras dos Padres da Igreja”. ${ }^{34}$ Após ridicularizar a paixão oratória de certos indivíduos "em nossas raças tagarelas" [dans nos races jacassières] e admitir seu desprezo por essas vítimas da "efusão oratória" [effusions oratoires], o poeta se encaminha para o encerramento do poema recorrendo a citações de dois moralistas franceses:

"Essa grande desgraça de não poder estar sozinho! ...", diz em algum lugar La Bruyère, como para envergonhar aqueles que se apressam em se esquecer na multidão, talvez temendo não conseguir suportar a si mesmos.

"Quase todas as nossas desgraças ocorrem por não termos sabido permanecer no nosso quarto", diz um outro sábio, Pascal, eu acho, lembrando, assim, no claustro do recolhimento, todos os afobados que procuram a felicidade no movimento e numa prostituição que eu poderia chamar fraternitária, se quisesse falar a bela língua do meu século (I, p. 314, grifo do autor). ${ }^{35}$

Baudelaireopõea solidãoàquiloquechama "prostituiçãofraternitária", fazendo uso de um neologismo que remete à noção de fraternidade, ao pensamento social da época e ao republicanismo humanitarista representado especialmente por Proudhon (LABARTHE, 200o, pp. 92-99). Esse tipo negativo de prostituição está, portanto, associado à massificação

34 "[...] un gazetier philanthrope me dit que la solitude est mauvaise pour l'homme; et à l'appui de sa thèse, il cité, comme tous les incrédules, des paroles des Pères de l'Église."

35 “'Ce grand malheur de ne pouvoir être seul!...' dit quelque part La Bruyère, comme pour faire honte à tous ceux qui courent à s'oublier dans la foule, craignant sans doute de ne pouvoir se supporter eux-mêmes. / 'Presque tous nos malheurs nous viennent de n'avoir pas su rester dans notre chambre', dit un autre sage, Pascal, je crois, rappelant ainsi dans la cellule du recueillement tous ces affolés qui cherchent le bonheur dans le mouvement et dans une prostitution que je pourrais appeler fraternitaire, si je voulais parler la belle langue de mon siècle."

Remate de Males, Campinas-SP, v. 37, n. 1, pp. 93-116, jan./jun. 2017 
das opiniões e das ideias. Na contramão disso, o poeta entende que o homem de gênio deve resguardar sua individualidade, em oposição ao homem comum; contudo, ele deve também se abrir para o contato com o mundo, num tipo particular de prostituição, como em "Mon coeur mis à nu": "Gosto invencível da prostituição no coração do homem, de onde nasce seu horror da solidão. - Ele quer ser dois. O homem de gênio quer ser um, portanto, solitário. A glória é permanecer um, e se prostituir de uma maneira particular" (I, p. 70o, grifos do autor)..$^{36}$

Diferente da "prostituição fraternitária", a prostituição particular à qual se entrega o artista moderno associa-se a um movimento de mergulho na multidão urbana, a uma abertura para o coletivo que pressupõe ao mesmo tempo um encontro e a manutenção da individualidade. Para Baudelaire (I, p. 291), “o poeta goza do incomparável privilégio de poder ser, à sua guisa, ele mesmo e outra pessoa. Como essas almas errantes que procuram um corpo, ele entra, quando quer, no personagem de cada um" ("Les foules"). ${ }^{37}$ "Entrar no personagem" alheio pressupõe uma dinâmica de ida e volta, de dispersão na multidão e retorno à solidão, que lembra a fórmula célebre com a qual se abre "Mon coeur mis à nu": "Da vaporização e da centralização do Eu. Tudo se resume a isso" (I, p. 676, grifo do autor). $3^{8}$ No Spleen de Paris - "À une heure du matin" -, esse retorno à solidão, ao espaço da individualidade é, não raro, representado pela imagem do quarto ou do apartamento, no qual o poeta se fecha com uma "dupla volta na chave" [double tour à la serrure], para se ver livre, ainda que por poucas horas, da "tirania da face humana" [tyrannie de la face humaine] (I, p. 287).

A mesma dinâmica de aproximação e distanciamento identificada na relação do poeta com a multidão pode ser verificada também na busca pelo espaço público do jornal. Assim como o poeta que perde sua auréola, a poesia também precisa se disfarçar para penetrar e ser aceita no espaço público dos jornais. A passagem para a prosa, por si só, já representa uma abertura considerável à comunicabilidade, pois se apresenta, não somente como uma revolução formal, mas principalmente como uma nova ideia de

36 "Goût invincible de la prostitution dans le cœur de l'homme, d'où naît son horreur de la solitude. - Il veut être deux. L'homme de génie veut être un, donc solitaire. La gloire, c'est rester un, et se prostituer d'une manière particulière."

37 "[...] le poète jouit de cet incomparable privilège, qu'il peut à sa guise être lui-même et autrui. Comme ces âmes errantes qui cherchent un corps, il entre, quand il veut, dans le personnage de chacun."

38 "De la vaporisation et de la centralisation du Moi. Tout est là."

Remate de Males, Campinas-SP, v. 37, n. 1, pp. 93-116, jan./jun. 2017 
poesia, que inclui a adesão a novos temas e ao caráter fragmentado do gênero jornalístico. Poderia enumerar aqui diversos exemplos da adesão dos poemas em prosa ao estilo ensaístico e anedótico que prevalece nos jornais da época, mas prefiro concentrar-me no caso exemplar do poema "Les yeux des pauvres", cujo estilo anedótico e o cenário atualíssimo de um café parisiense adequaram-se perfeitamente ao jornal La vie parisienne, que o acolheu pela primeira vez na edição de 2 de julho de 1864, sem assinatura e sem qualquer marca indicativa de gênero. Em meio aos outros textos do jornal, é bem provável que a história anônima de um encontro amoroso em um novo café situado em um novo bulevar da Paris haussmanianna não tenha sido lida, na ocasião, como um poema. Os leitores que abriram La vie parisienne naquele 2 de julho se depararam com o texto de Baudelaire precedido de três relatos anedóticos publicados sob o título "Types de femmes". Considerando o protagonismo da mulher em "Les yeux des pauvres", ele não poderia muito bem ter sido lido naquele contexto como mais uma anedota, aparentada às anteriores? É a pergunta que se faz Shoichiro Iwakiri, em artigo dedicado a analisar a publicação de dois poemas em prosa ("Les projets" e "Les yeux des pauvres") no jornal $L a$ vie parisienne. Na conclusão de sua análise, que subscrevo sem ressalvas, o crítico japonês afirma que:

[...] a inserção dos "Yeux des pauvres" em La vie parisienne é comparável à descida do poeta antes aureolado em um "mau lugar", na medida em que a prosa de Baudelaire sem assinatura se introduz incógnita entre outras prosas sem nenhum atributo do gênero poesia (IWAKIRI, 2011, p. 192, grifos do autor). ${ }^{39}$

Incógnita nas páginas do jornal, como o poeta sem auréola nas ruas da cidade, a poesia penetra, pela primeira vez na história, esse espaço estranho à tradição lírica. Seu disfarce de prosa anedótica não impede o leitor atento, contudo, de identificar nela a marca de sua distinção: a ironia cortante que, não raro, é desferida contra o próprio leitor ou contra o próprio jornal, como se vê em pomas como "Le chien et le flacon", "À une heure du matin" e "Le gâteau". Por trás do disfarce do poema, percebe-se o refluxo do movimento de aproximação que a prosa simula em relação ao mundo, em relação à "bela língua do século" [la belle langue de [mon]

39 "L'insertion des Yeux des pauvres dans la La vie parisienne est comparable à la descente du poète jadis auréole dans un 'mauvais lieu', dans la mesure où la prose de Baudelaire sans signature s'introduit incognito parmi d'autres proses sans aucun attribut du genre poésie." 
siècle] (I, p. 314), em relação aos jornais. ${ }^{40}$ Disfarçada, a poesia percorre incógnita o espaço coletivo dos jornais sem, contudo, perder-se nele, sem jamais aderir à "prostituição fraternitária", sem abrir mão de sua solidão.

\section{Bagatelas laboriosas}

Aos elementos que considero importantes para um estudo do Spleen de Paris é preciso acrescentar um breve comentário sobre a maneira como o poeta, principalmente em suas correspondência, se expressou a respeito de seu próprio projeto. O princípio do disfarce prevalece também no discurso de Baudelaire sobre a prosa poética, que pretendia destinar aos jornais. Em diversas cartas enviadas a editores e intelectuais da época, o poeta revela uma visão antinômica e irônica desses mesmos poemas. Chama a atenção, em primeiro lugar, a tonalidade displicente com a qual ele se refere ao próprio trabalho. Em maio de 1865 , o poeta conta a Édouard Manet que possui uma "massa de poemas em prosa para espalhar em duas ou três revistas" (C, II, p. 497, grifo do autor). ${ }^{41}$ Meses antes, em duas oportunidades, Baudelaire prometera entregar ao editor Louis Marcelin um "pacote de poemas em prosa" [paquet de poèmes en prose] (C, II, pp. 406 e 465). Essas duas imagens apontam claramente para uma visão banalizada e comercial da poesia, ironicamente associada a uma mercadoria, como no poema L'horloge, em que o poeta oferece seu "madrigal" a uma mulher, simulando uma interlocução com uma cliente, mas enfatizando, por fim, que não pediria nada em troca por seu trabalho de "bordado" (I, p. 30o), num jogo retórico que multiplica as camadas de

40 É importante ter em mente que Baudelaire foi um grande crítico do jornalismo e dos jornalistas de seu tempo, apesar de manter relações comerciais e de colaboração com muitos deles. No fragmento XLIV de "Mon coeur mis à nu", os jornais são atacados de maneira explícita como verdadeiros compêndios de horrores: "Todo jornal, da primeira linha à última, não passa de um tecido de horrores. Guerras, crimes, roubos, lascividade, torturas, crimes de príncipes, crime de nações, crimes de particulares, uma embriaguez de atrocidade universal. E é com esse nojento aperitivo que o homem civilizado acompanha sua refeição toda manhã. Tudo, nesse mundo, transpira crime: o jornal, a muralha, o rosto do homem. Não compreendo como uma mão possa tocar um jornal sem uma convulsão de nojo" [Tout journal, de la première ligne à la dernière, n'est qu'un tissu d'horreurs. Guerres, crimes, vols, impudicités, tortures, crimes des princes, crimes des nations, crimes des particulières, une ivresse d'atrocité universelle. Et est de ce dégoûtant apéritif que l'homme civilisé accompagne son repas de chaque matin. Tout, en ce monde, sue le crime : le journal, la muraille et le visage de l'homme. Je ne comprends pas qu'une main pure puisse toucher un journal sans une convulsion de dégoût.] (I, pp. 705-706).

41 "[...] une masse de Poèmes en prose à répandre dans deux ou trois revues."

Remate de Males, Campinas-SP, v. 37, n. 1, pp. 93-116, jan./jun. 2017 
significação do texto, que permanece suspenso entre a retórica comercial simulada pelo poeta-vendedor e a intransitividade do artesanato poético que coloca o prazer acima da mercadoria. "Pacote”, aliás, é uma palavra que retorna à pluma de Baudelaire (I, p. 284, grifo nosso) no desfecho de Le chien et le flacon, outro poema que alegoriza a relação com o público, dessa vez de maneira bem mais agressiva:

- Ah! miserável cão, se eu tivesse te oferecido um pacote de excrementos, tu o terias farejado com deleite e talvez até devorado. Assim, indigno companheiro de minha triste vida, tu te pareces com o público, ao qual não se deve jamais apresentar perfumes delicados que o exasperem, mas dejetos cuidadosamente escolhidos..$^{2}$

A julgar pelo paralelismo retórico existente entre o poema e as afirmações epistolares de Baudelaire, os poemas em prosa se aproximam dos excrementos e, conforme o desenvolvimento do raciocínioapresentado pelo poeta, dos “dejetos cuidadosamente escolhidos" para o público. Entre o rebaixamento retórico ao qual submete o poema em prosa e o trabalho poético por trás desse procedimento, o poeta constrói uma poética antinômica que se define pela dinâmica da própria contradição. Suas "bagatelas laboriosas" [bagatelles laborieuses] (C, II, p. 493) reproduzem na forma e no conteúdo o próprio lugar incerto do poeta e da poesia no mundo moderno, e a história de seus poemas em prosa, destinados a transitarem entre a fragmentação do jornal e a unidade de um livro sempre porvir, reconstitui com perfeição, em seu próprio dinamismo, esse organismo estranho, "sem rabo nem cabeça" [ni queue ni tête] (I, p. 275), planejado pelo poeta e realizado postumamente por seus amigos. Qualquer abordagem do conjunto dos poemas em prosa de Baudelaire não pode negligenciar esse movimento perpétuo de aproximação e distanciamento, abertura e fechamento, "centralização" e "vaporização" que define a arquitetura móvel do Spleen de Paris.

\section{REFERÊNCIAS BIBLIOGRÁFICAS}

BAUDELAIRE, Charles. Petits poèmes en prose. Édition de Robert Kopp. Paris: Librairie José Corti, 1968.

42 "Ah! misérable chien, si je vous avais offert un paquet d'excréments, vous l'auriez flairé avec délices et peut-être dévoré. Ainsi, vous-même, indigne compagnon de ma triste vie, vous ressemblez au public, à qui il ne faut jamais présenter des parfums délicats qui l'exaspèrent, mais des ordures soigneusement choisies." 
A poesia incógnita: elementos de um estudo da poética do Spleen de Paris - 115

BAUDELAIRE, Charles. Correspondance. Texte établi, présenté et annoté par Claude Pichois avec la collaboration de Jean Ziegler. Paris: Gallimard, 1973, 2v. (Coll. Bibliothèque de la Pléiade)

BAUDELAIRE, Charles. Euvres complètes. 2 vols. Texte établi, présenté et annoté par Claude Pichois. Paris: Gallimard, 1975-1976. (Coll. Bibliothèque de la Pléiade)

BENJAMIN, Walter. Charles Baudelaire um lírico no auge do capitalismo. Trad. José Martins Barbosa e Hemerson Alves Baptista. São Paulo: Brasiliense, 1989. (Obras Escolhidas III)

BONNEFOY, Yves. Le siècle de Baudelaire. Paris: Seuil, 2014.

COMPAGNON, Antoine. Les antimodernes: de Joseph de Maistre à Roland Barthes. Paris: Gallimard, 2005.

COMPAGNON, Antoine. Baudelaire l'irréductible. Paris: Flammarion, 2014.

DUPONT, Jacques. Le spleen de Paris, une fiction critique? L'année Baudelaire, v. 16, 2012. Paris: Honoré Champion, 2013, pp. 41-54.

FRIEDRICH, Hugo. Estrutura da lírica moderna: da metade do século XIX a meados do século XX. Trad. Marise Curioni e Dora da Silva. São Paulo: Duas Cidades, 1991.

GLEIZE, Jean-Marie. Les chiens s'approchent, et s'éloignent. ALEA, v. 9, no 2, jul.-dez. 2007, pp. 165-175.

IWAKIRI, Shoichiro. Autoportrait du poème en prose. L'année Baudelaire, v. 13/14, 2009/2010. Paris: Honoré Champion, 2011, pp. 181-193.

JOHNSON, Barbara. Défigurations du langage poétique: la seconde révolution baudelairienne. Paris: Flammarion, 1979.

KAPLAN, Edward K. Baudelaire et Le spleen de Paris. L'esthétique, l'éthique et le religieux. Trad. Élise Trogrlic. Paris: Classiques Garnier, 2015.

LABARTHE, Patrick. Patrick Labarthe commente les "Petits poèmes en prose" de Baudelaire. Paris: Gallimard, 2000.

LAWLER, James. L'ouverture des Fleurs du mal. In: BERCOT, Martine \& GUYAUX, André (orgs.). Dix études sur Baudelaire. Paris: Honoré Champion, 1993, pp. 7-33.

MURPHY, Steve. Logiques du dernier Baudelaire: lectures du Spleen de Paris. Paris: Honoré Champion, 2007. (Colection Champion Classiques)

SCHELLINO, Andrea. Baudelaire et la prostitution "fraternitaire", à propôs de "La solitude". Méthode! Revue de Littérture, Université de Pau, Vougeois, no 24, 2014, pp. 183-194. 
A poesia incógnita: elementos de um estudo da poética do Spleen de Paris - 116

YOKOHARI, Makoto. L'incognito, condition de la modernité. L'année Baudelaire, v. 13/14, 2009/2010. Paris: Honoré Champion, 2011, pp. 119-135. 